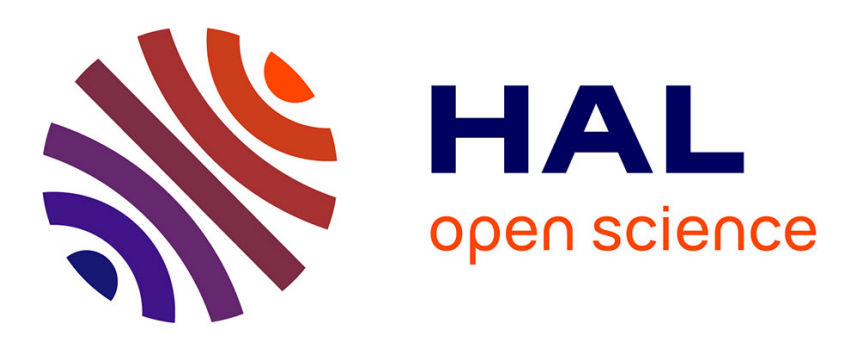

\title{
Glucose promotion of GABA metabolism contributes to the stimulation of insulin secretion in b-cells
} Javier Pizarro-Delgado, Matthias Braun, Ines Hernandez-Fisac, Rafael Martin-Del-Rio, Jorge Tamarit-Rodriguez

\section{- To cite this version:}

Javier Pizarro-Delgado, Matthias Braun, Ines Hernandez-Fisac, Rafael Martin-Del-Rio, Jorge Tamarit-Rodriguez. Glucose promotion of GABA metabolism contributes to the stimulation of insulin secretion in b-cells. Biochemical Journal, 2010, 431 (3), pp.381-389. 10.1042/BJ20100714 . hal-00525045

\section{HAL Id: hal-00525045 \\ https://hal.science/hal-00525045}

Submitted on 11 Oct 2010

HAL is a multi-disciplinary open access archive for the deposit and dissemination of scientific research documents, whether they are published or not. The documents may come from teaching and research institutions in France or abroad, or from public or private research centers.
L'archive ouverte pluridisciplinaire HAL, est destinée au dépôt et à la diffusion de documents scientifiques de niveau recherche, publiés ou non, émanant des établissements d'enseignement et de recherche français ou étrangers, des laboratoires publics ou privés. 


\section{GLUCOSE PROMOTION OF GABA METABOLISM CONTRIBUTES TO THE STIMULATION OF INSULIN SECRETION IN $\beta$-CELLS}

Short Title: Stimulation of islet insulin secretion by an increased GABA metabolism

Keywords: GABA, glucose, insulin, pancreatic islets, GAD, GABA transaminase

Javier Pizarro-Delgado ${ }^{1}$, Matthias Braun ${ }^{2}$, Inés Hernández-Fisac ${ }^{1}$, Rafael Martín-delRío $^{3}$, and Jorge Tamarit-Rodriguez ${ }^{1}$

${ }^{1}$ Department of Biochemistry, Medical School, Complutense University, Madrid-28040, Spain; ${ }^{2}$ Oxford Centre for Diabetes, Endocrinology and Metabolism, Churchill Hospital, Old Road, Oxford OX3 7LJ, UK; ${ }^{3}$ Research Department, Hospital "Ramón y Cajal, , Madrid-28034, Spain

Corresponding author:

Jorge Tamarit-Rodriguez, Biochemistry Department, Medical School, Complutense University, Madrid-28040, Spain

Phone: +34-913941449

Fax: +34-913941691

e-mail: tamarit@med.ucm.es

\footnotetext{
${ }^{1}$ Abbreviations: GABA ( $\gamma$-amino butyric acid); SSA (succinic acid semialdehyde); KIC (oxo-4-methylpentanoate or $\alpha$-ketoisocaproate); GAD (glutamic acid decarboxylase); GABA-T (GABA transaminase); SSA-R (semialdehyde succinic acid reductase); SSAdh (semialdehyde succinic acid dehydrogenase; KRBH (Krebs-Ringer bicarbonate HEPES buffer; 2-OG-dh (2-oxoglutarate dehydrogenase); Succ-dh (succinic acid dehydrogenase); MAD (malonic acid dimethyl ester); $\mathrm{K}_{\text {ATP }}$ channel (ATP sensitive $\mathrm{K}^{+}$ channel)
} 


\section{SYNOPSIS}

We have recently demonstrated that branched-chain $\alpha$-ketoacid stimulation of insulin secretion is dependent on islet GABA metabolism: GABA transamination to semialdehyde succinic acid is increased by 2-oxoglutarate, generated in $\alpha$-ketoacid transamination to its corresponding $\alpha$-amino acid. This work aimed at investigating whether glucose also promotes islet GABA metabolism and whether the latter contributes to the stimulation of insulin secretion. Glucose $(20 \mathrm{mM})$ decreased both the content and release of islet GABA. Gabaculine $(1 \mathrm{mM})$, a GABA transaminase inhibitor, partially suppressed the secretory response of rat perifused islets to $20 \mathrm{mM}$ glucose at different L-glutamine concentrations $(0,1$ and $10 \mathrm{mM})$ as well as sugarinduced decrease of islet GABA. The drug also reduced islet ATP content and the ATP/ADP ratio at $20 \mathrm{mM}$ glucose. Exogenous semialdhyde succinic acid dose-dependently increased islet GABA content by reversal of GABA transamination and induced biphasic insulin secretion in the absence of glucose. It depolarized isolated $\beta$-cells and triggered action potential firing, accompanied by a reduction of membrane currents through ATP-sensitive $\mathrm{K}^{+}$channels. Gene expression and enzyme activity of GABA transaminase were several-fold higher than those of 2-oxoglutarate dehydrogenase in islet homogenates. We conclude that, at high glucose concentrations, there is an increased diversion of glucose metabolism from the citric acid cycle into the "GABA shunt". Semialdehyde succinic acid is a permeable "GABA-shunt" metabolite that increases ATP and the ATP/ADP ratio, depolarizes $\beta$-cells, and stimulates insulin secretion. In summary, an increased islet GABA metabolism may trigger insulin secretion.

\section{INTRODUCTION}

Pancreatic $\beta$-cells contain high amounts of GABA [1-2] and express glutamic acid decarboxylase (GAD, isoforms 65 and 67), which catalyzes its synthesis [3-6]. GABA localizes to the rough endoplasmic reticulum, mitochondria and synaptic-like microvesicles (SLMV) [7, 8]. Recent studies also suggest that GABA is taken up by the insulin-containing secretory granules $[8,9]$. GABA uptake into secretory vesicles is mediated by the vesicular GABA transporter VGAT and dependent on a proton gradient generated by the vesicular $\mathrm{H}^{+}$-ATPase $[10,11]$. GABA is subsequently released from $\beta$ cells by regulated exocytosis [9] and a poorly characterized but quantitatively important tonic release by a non-vesicular mechanism $[9,12]$.

GABA released from $\beta$-cells has been shown to exert a paracrine inhibitory effect on glucagon secretion from neighbouring $\alpha$-cells [13-15] as well as an autocrine suppressor effect on insulin secretion [16]. The presence of $\mathrm{GABA}_{\mathrm{B}}$-receptors in $\beta$-cells $[16,17]$ and of $\mathrm{GABA}_{\mathrm{A}}$-receptors in $\alpha$-cells $[13,15]$ supports the putative autocrine/paracrine role of locally secreted GABA in islets.

Although an intracellular function of GABA in $\beta$-cells has also been suggested [18], this area is less well explored. The presence of all enzymatic activities required for the function of the "GABA-shunt" has been demonstrated in islet homogenates [3-6, 1922]. GABA is produced by the decarboxylation of Glu (by glutamic acid decarboxylase, GAD) and it enters the "GABA-shunt" after its transamination with 2-oxoglutarate (GABA transaminase, GABA-T) to succinic acid semialdehyde (SSA) and Glu. SSA may be oxidized to succinic acid (NAD ${ }^{+}$-dependent SSA dehydrogenase, SSA-dh) and enter the citric acid cycle. Alternatively, SSA might be reduced to $\gamma$-aminobutyric acid $\left(\mathrm{NADP}^{+}\right.$-dependent SSA reductase, SSA-R) and exit the "GABA-shunt" (see the 
scheme in reference 25). GABA has a high metabolic turnover rate in islets [20] determined by the balance between synthesis, catabolism, and release. Acutely, glucose stimulates GABA release from $\beta$-cells over-expressing $\mathrm{GABA}_{\mathrm{A}}$-receptors [22]. By contrast, in long-term experiments $(1-24 \mathrm{~h})$ high glucose promotes islet GABA catabolism and decreases its content, resulting in a lower rate of release [21]. It has been shown that increasing the extracellular L-glutamine concentration increases both islet GABA content and GABA release [19-22]. While a decreased GABA content has been associated with an increased insulin secretion [21], overexpression of GAD65 in transgenic mice or INS-1 cells results in impaired insulin release [23, 24] but it was not determined whether intracellular GABA levels were correspondingly modified.

We could recently demonstrate that oxo-4-methylpentanoic acid (KIC) promotes islet cells GABA metabolism whose inhibition by gabaculin suppresses insulin secretion [20, 25]: oxo-4-methylpenanoic acid (KIC) transamination to L-leucine at the expenses of Glu generates 2-oxoglutarate that may be used by GABA-transaminase (GABA-T) to initiate "GABA-shunt" metabolism. As glucose metabolism in the citric acid cycle can also generate 2-oxoglutarate, the latter might also be used by GABA-T to promote "GABA-shunt" metabolism. Therefore, we have investigated how glucose affects intracellular GABA metabolism and whether this contributes to the stimulation of insulin secretion.

\section{EXPERIMENTAL}

\section{Materials}

Collagenase $\mathrm{P}$ and free-FFA bovine serum albumin were obtained from Roche Diagnostics S.L. (Barcelona, Spain). Gabaculine, bovine serum albumin and most of the substances, enzymes and coenzymes were obtained from Sigma-Aldrich Química S.A. (Madrid, Spain). Rat insulin was from Linco Research, Inc. (St. Charles, Missouri, U.S.A.). $\mathrm{Na}^{125}$ I was obtained from PerkinElmer España, S.L. (Madrid, Spain). Inorganic compounds and organic solvents were obtained from VWR International Eurolab S.L.(Spain).

\section{Islet insulin secretion}

Islets were isolated from the pancreas of male Wistar-albino rats (250-275 g BW) by collagenase digestion. Insulin secretion was studied in perifused islets. Four groups, each of 40 rat islets, were perifused in parallel and at a flow rate of $0.5 \mathrm{ml} / \mathrm{min}$ with Krebs-Ringer, buffered with $0.5 \mathrm{mM} \mathrm{NaHCO}_{3}$ and $20 \mathrm{mM}$ HEPES, supplemented with $0.5 \%$ FFA-free BSA $(\mathrm{KRBH})$, and heated at $37^{\circ} \mathrm{C}$. The perifusion pattern was similar in all the experiments. After a pre-perifusion period of 45 minutes under basal conditions (in the absence of nutrients or at $5 \mathrm{mM}$ glucose), the perifusion medium was switched to one containing the test substances and maintained for the next 30 minutes. Finally, the medium was changed back to pre-perifusion conditions where it was maintained for the last 25 minutes. The perifusate was collected at 1 minute intervals during the last 60-70 minutes of perifusion and its insulin concentration radioimmunologically measured. Pig insulin was radio-iodinated with $\mathrm{Na}^{125} \mathrm{I}$ [26] and rat insulin was used as a standard in the radioimmunoassay of insulin. Insulin antiserum was kindly provided by Dr. Janove Sehlin from the Department of Medical Cell Biology at the University of Umeå (Sweden).

\section{Islet amino acid measurement}

Islet amino acids were separated by reverse-phase HPLC after precolumn derivatization with o-phthalaldialdehyde [27] and quantified by fluorescence detection. The content and release of the measured islet amino acids (Asp, Glu, Ser, Gln, His, Gly, Thr, Arg, Tau, Ala, Tyr, and GABA) were studied following previously published methods [19, 
20]. Three groups, each of 20 to 30 islets, were pre-incubated for 1 hour at $37^{\circ} \mathrm{C}$ with different Gln concentrations. After discarding the medium and washing the islets twice with saline, they were further incubated for a second hour at 0 or $20 \mathrm{mM}$ glucose. In the cases in which amino acid release was not studied, the islets were only incubated for 1 hour. The incubations were stopped by placing the islets on ice. Islets were washed twice with PBS and their amino acids extracted with 35\% (w/v) 5-sulfosalicylic acid. Aliquots of the incubation medium were also saved for measurements of amino acid release. The amount of protein was measured in the islet extracts with the method of Lowry [28] and BSA was used as the standard.

\section{Islet adenine nucleotides measurement}

Total islet ATP content was measured with the luciferin-luciferase system [18]. Islets (groups of 25) were incubated at $37{ }^{\circ} \mathrm{C}$ for 60 minutes in $25 \mu 1$ of $\mathrm{KRBH}+\mathrm{BSA}$. The incubation was stopped on acetone chilled with dry ice and $20 \mu \mathrm{l}$ of $1.35 \mathrm{M}$ perchloric (PCA) were added. PCA was neutralized and precipitated with $15 \mu 1$ of $0.1 \mathrm{M}$ Tris +2.8 $\mathrm{M} \mathrm{KHCO}_{3}$. Supernatant aliquots and ATP standard solutions $(1-50 \mu \mathrm{M})$ were then added to a luciferin-luciferase mixture and the emitted light was measured in a bioluminometer. Luciferase $(1 \mathrm{mg} / \mathrm{ml})$ and D-luciferin $(0.1 \mathrm{mM})$ were dissolved in a buffer containing $50 \mathrm{mM}$ HEPES, $10 \mathrm{mM} \mathrm{MgCl}_{2}$, and $0.1 \%(\mathrm{w} / \mathrm{v})$ fatty acid-free BSA, and adjusted to $\mathrm{pH}$ 7.6. The luciferin-luciferase mixture was prepared by adding $10 \mu 1$ of the luciferase solution to $400 \mu \mathrm{l}$ of $0.1 \mathrm{mM}$ luciferin. ADP was converted to ATP by pyruvate kinase $(10 \mathrm{IU} / \mathrm{ml})$ in the presence of $1 \mathrm{mM}$ phosphoenolpyruvate.

\section{RNA extraction and retrotranscription}

Total RNA was harvested from four rats' livers $(<20 \mathrm{mg})$ and from each group of islets isolated from six rats using the RNeasy ${ }^{\circledR}$ Mini, RNA isolation kit (Qiagen, Izasa S.A., Madrid, Spain) and total RNA from cerebellum $(<100 \mathrm{mg})$ was harvested from three rats using RNeasy Lipid Tissue Mini Kit (Qiagen, Izasa S.A., Madrid, Spain), according to manufacturer's protocol. Total RNA was eluted from the RNeasy ${ }^{B}$ Mini columns with $30 \mu \mathrm{l}$ of RNase-free water. RNA retrotranscription was performed with the Quantitect $^{\circledR}$ Reverse Transcription Kit (Qiagen, Izasa S.A., Madrid, Spain), as per manufacturer's instructions.

\section{Real-time quantitative PCR}

Succinic dehydrogenase, GABA transaminase, 2-oxoglutarate dehydrogenase (E2 subunit), semialdehyde succinic reductase (AKR7A2) and glutamic acid decarboxylase (GAD65) genes expression were evaluated using TaqMan ${ }^{\circledR}$ Gene Expression Assays (20X) (Applied Biosystems, Applera Hispania S.A., Madrid, Spain). Semialdehyde succinic dehydrogenase gene expression was evaluated using Custom Gene Expression Assay (20X) (Applied Biosystems, Applera Hispania S.A., Madrid, Spain) using the extreme 3' end of the genetic sequence (L34821). Two internal controls were used: 18S for tissue-comparison and GAPDH for intra-islet comparison (TaqMan ${ }^{\circledR}$ Gene Expression Assays (20X), Applied Biosystems, Applera Hispania S.A., Madrid, Spain). FastStart TaqMan ${ }^{\circledR}$ Probe Master (Rox) (Roche Diagnostics S.L.) supplemented with Rox (Roche Diagnostics S.L.) to $820 \mathrm{nM}$ was used as master mix. Amplification was performed in a 7300 Real Time PCR System (Applied Biosystems, Applera Hispania S.A.). Gene expression is represented as $2^{-\Delta \Delta \mathrm{Ct}}$ values and the statistical comparisons made between mean $2^{-\Delta \mathrm{Ct}}$ values of 3 to 6 experiments.

\section{Enzymes' activities}

Isolated islets were homogenized by sonication (four times, ten strokes at 10-20\% of the cycle and the minimum potency of a Branson sonifier 450) in a buffer containing $10 \mathrm{mM} \mathrm{KH}_{2} \mathrm{PO}_{4}, 0.5 \mathrm{mM}$ EDTA, leupeptin $(60 \mu \mathrm{M})$, aprotinin $(0.019 \mathrm{TIU} / \mathrm{ml})$, PMSF (2 $\mathrm{mM}$ in DMSO), $\beta$-mercaptoethanol $(10 \mathrm{mM})$, and Triton-X100 $(0.5 \%$, vol/vol $)(\mathrm{pH}=$ 
7.2). The islet homogenate was then centrifuged at $4^{0} \mathrm{C}$ and $141,500 \mathrm{~g}$ for 30 minutes in a 100.Ti rotor of the ultracentrifuge model Optima ${ }^{\mathrm{TM}}$-L-100 XP (Beckman Coulter España S.A.).

2-Oxoglutarate dehydrogenase (2-OG-dh) activity in islets' homogenates was studied as the amount of NADH produced at saturating concentrations of 2-oxoglutarate $(10 \mathrm{mM})$ and $\mathrm{NAD}^{+}(2.5 \mathrm{mM})$ and measured fluorometrically in a multiwell plate (Costar assay plate no. 3915, Corning Incorporated, NY, U.S.A.) recorder (Varioskan model, Bioanalysis Labsystems S.A., Barcelona, Spain). The enzyme reaction was performed in a $50 \mathrm{mM} \mathrm{KH} \mathrm{PO}_{4}$ buffer $(\mathrm{pH}=7.2)$ supplemented with $4 \mu \mathrm{M}$ rotenone, $0.5 \mathrm{mM}$ coenzyme A, $0.3 \mathrm{mM}$ thiamine pyrophosphate, $2.5 \mathrm{mM}$ dithiotreitol, $2 \mathrm{mM}$ GTP, 0.8 $\mathrm{mM} \mathrm{CaCl} 2,1 \mathrm{mM} \mathrm{MgCl}, 5 \mathrm{mg} / \mathrm{ml} \mathrm{BSA}$ and the substrates.

GABA transaminase (GABA-T) activity in islets' homogenates was studied as the amount of NADH produced at saturating concentrations of succinic acid semialdehyde (SSA, $10 \mathrm{mM})$, Glu $(5 \mathrm{mM})$ and $\mathrm{NAD}^{+}(2.5 \mathrm{mM})$ in the presence of exogenous 2oxoglutarate dehydrogenase $(0.18 \mathrm{IU} / \mathrm{ml})$ and measured as described above. The enzyme reaction was performed in the same buffer used for $2-\mathrm{OG}-\mathrm{dh}(\mathrm{pH}=7.2)$. In parallel aliquots of islet homogenates, the activity of SSA dehydrogenase (SSA-dh) was measured in the absence of exogenous 2-OG-dh and this activity was subtracted from the overall GABA transaminase reaction. All enzyme activities were calculated as the slopes of the linear increase of NADH fluorescence expressed as the amount of formed product / min x mg protein by reference to a nucleotide standard curve. The amount of protein was measured in the islet extracts with the method of Lowry [21] and BSA was used as the standard.

\section{Electrophysiology}

Patch-clamp experiments performed in the perforated-patch whole-cell configuration, using an EPC9 patch-clamp amplifier and Pulse software (HEKA Electronics, Lambrecht, Germany). The extracellular solution consisted of (in $\mathrm{mM}$ ) $140 \mathrm{NaCl}, 3.6$ $\mathrm{KCl}, 0.5 \mathrm{MgSO}_{4}, 1.5 \mathrm{CaCl}_{2}, 10 \mathrm{HEPES}, 0.5 \mathrm{NaH}_{2} \mathrm{PO}_{4}, 5 \mathrm{NaHCO}_{3}$ (pH adjusted to 7.4 with $\mathrm{NaOH}$ ) and 1 glucose. The pipette solution contained (in $\mathrm{mM}$ ) $76 \mathrm{~K}_{2} \mathrm{SO}_{4}, 10 \mathrm{KCl}$, $10 \mathrm{NaCl}, 1 \mathrm{MgCl}_{2}$ and 5 HEPES (pH 7.35 with $\mathrm{KOH}$ ). Electrical contact was established by inclusion of amphotericin $\mathrm{B}(0.24 \mathrm{mg} / \mathrm{ml})$ in the pipette solution. $\beta$-cells were identified based on the inactivation properties of voltage-gated $\mathrm{Na}^{+}$-currents. All measurements were carried out at $32-33^{\circ} \mathrm{C}$.

\section{RESULTS \\ Islet amino acids}

We examined the effects of extracellular Gln on the islet content of Asp, Gln, Glu and GABA. Rat islets were first incubated in the presence of increasing concentrations of Gln during one hour, followed by incubation in the absence of Gln for another hour at either 0 or $20 \mathrm{mM}$ glucose. The amounts of amino acids within the islets were determined at the end of the second hour. Gln induced a concentration-dependent increase in the islet content of Glu (Fig. 1A), Asp (Fig. 1B) and GABA (Fig. 1C), but not Gln (results not shown). Glucose $(20 \mathrm{mM})$ reduced the islet content of Glu in the absence of Gln (Fig. 1A) but did not modify the content of GABA under these conditions (Fig. 1C). GABA content was reduced by glucose by $\sim 40 \%$ in islets preloaded with either $0.5(p<0.01)$ or $10 \mathrm{mM} \mathrm{Gln}(\mathrm{p}<0.001$; Fig. $1 \mathrm{C})$. The amounts of the amino acids measured in the extracellular medium at the end of the second hour provide an estimate of the overall rate of release. Glucose $(20 \mathrm{mM})$ decreased the release of 
Asp, Glu, and GABA by 14-75\% (1A-C, right). It also reduced Gln release from islets pre-exposed to $10 \mathrm{mM}$ Gln during the first hour (result not shown). Fig. 1D summarizes the correlation between GABA content measured at the $0,0.5$ and $10 \mathrm{mM}$ Gln and the amount of GABA released. It can be seen that release is linearly related to the content of the amino acid $(r=0.95 \pm 0.15, n=6 ; p=0.01)$.

As islet GABA content was decreased by $20 \mathrm{mM}$ glucose without any concomitant increase of amine release, it was assumed that an increased GABA metabolism might have occurred. D-Mannoheptulose, a specific competitive glucokinase inhibitor [29], was used to confirm if the observed decrease of islet GABA content was dependent on glucose metabolism. $10 \mathrm{mM}$ D-mannoheptulose increased the islet GABA content at 20 $\mathrm{mM}$ glucose by more than 70\% whereas neither $10 \mathrm{mM}$ 2-deoxyglucose (noncompetitive inhibitor of low-Km-hexokinases), nor $10 \mathrm{mM}$ malonic acid dimethylester (MAD, a succinic acid dehydrogenase inhibitor) had any effect (online Fig, 1). Islet Asp was similarly increased by $10 \mathrm{mM}$ D-mannoheptulose, unaffected by $10 \mathrm{mM}$ 2-deoxyD-glucose but decreased by $10 \mathrm{mM}$ malonic acid dimethylester (online Fig.1). Measurement of the amino acid contents at the end of perifusion experiments (shown in Figure 4A) revealed that $1 \mathrm{mM}$ gabaculine, a specific GABA-T inhibitor [30], more than doubled islet GABA content at $20 \mathrm{mM}$ glucose $(104.8 \pm 12.6, \mathrm{n}=6$ vs. $51.6 \pm 10.1$ $\mathrm{pmol} / \mu \mathrm{g}$ islet protein, $\mathrm{n}=6 ; \mathrm{p}<0.009)$ and decreased Asp $(17.9 \pm 2.0, \mathrm{n}=5$ vs. $29.9 \pm$ $3.9 \mathrm{pmol} / \mu \mathrm{g}$ islet protein, $\mathrm{n}=5 ; \mathrm{p}<0.03$ ). Allylglycine, a precursor of a competitive inhibitor of glutamic acid decarboxylase (GAD) (31), suppressed basal levels of islet GABA (in the absence of any substrate) at a concentration of $10 \mathrm{mM}(31.2 \pm 2.8, \mathrm{n}=4$ vs. $49.1 \pm 2.8 \mathrm{pmol} / \mu \mathrm{g}$ islet protein, $\mathrm{n}=4 ; \mathrm{p}<0.004)$ or $20 \mathrm{mM}(31.1 \pm 1.8, \mathrm{n}=4 \mathrm{vs} .49 .1$ $\pm 2.8 \mathrm{pmol} / \mu \mathrm{g}$ islet protein, $\mathrm{n}=4 ; \mathrm{p}<0.002$ ). Semialdehyde succinic acid (SSA) is an intermediary metabolite in the "GABA shunt" pathway and originates in the transamination of GABA by a specific transaminase. As transamination is a reversible process, we checked whether SSA was membrane permeable and then able to increase the intracellular GABA concentration of islet cells. Islet GABA content was concentration-dependently increased by SSA ( $2 \mathrm{mM}: 64.5 \pm 10.5, \mathrm{n}=4$ vs. $49.1 \pm 2.8$ $\mathrm{pmol} / \mu \mathrm{g}$ islet protein, $\mathrm{n}=4$, N.S.; $5 \mathrm{mM}: 104.0 \pm 11.7, \mathrm{n}=4 \mathrm{vs} .49 .1 \pm 2.8 \mathrm{pmol} / \mu \mathrm{g}$ islet protein, $\mathrm{n}=4 ; \mathrm{p}<0.004 ; 10 \mathrm{mM}: 108.8 \pm 6.0, \mathrm{n}=4 \mathrm{vs} .49 .1 \pm 2.8 \mathrm{pmol} / \mu \mathrm{g}$ islet protein, $\mathrm{n}=4 ; \mathrm{p}<0.0001$ ). No significant change was observed in any of the other $\alpha$-amino acids measured.

\section{Islet ATP}

As expected, $20 \mathrm{mM}$ glucose increased islet ATP content $(4.61 \pm 0.08, \mathrm{n}=17$ vs. $2.82 \pm$ $0.14 \mathrm{pmol} /$ islet, $\mathrm{n}=18 ; \mathrm{p}<0.0001)$ as well as the ATP/ADP ratio $(2.14 \pm 0.16, \mathrm{n}=17 \mathrm{vs}$. $1.19 \pm 0.06, \mathrm{n}=18 ; \mathrm{p}<0.0001)$ by $60-80 \%$ in comparison with $3 \mathrm{mM}$ glucose. As shown in Figure 2, both islet ATP content and ATP/ADP ratio measured in the presence of 20 $\mathrm{mM}$ glucose were significantly decreased by incubation with $1 \mathrm{mM}$ gabaculine (without previous pre-treatment) irrespective of the L-glutamine concentration $(0,1$, or $10 \mathrm{mM})$. Oxo-4-methylpentanoic acid (KIC, $10 \mathrm{mM}$ ), a well known nutrient insulin secretagogue, increased islet ATP content $(4.4 \pm 0.1 \mathrm{n}=3$ vs. $2.8 \pm 0.1 \mathrm{pmol} /$ islet, $\mathrm{n}=$ $18 ; \mathrm{p}<0.0003)$ and the ATP/ADP ratio $(1.9 \pm 0.3, \mathrm{n}=2$ vs $1.2 \pm 0.06, \mathrm{n}=18 ; \mathrm{p}<0.003)$ in the presence of $3 \mathrm{mM}$ glucose. $1 \mathrm{mM}$ Gabaculine decreased the elevation of islet ATP content $(2.6 \pm 0.3, \mathrm{n}=3$ vs. $4.4 \pm 0.1 \mathrm{pmol} /$ islet, $\mathrm{n}=3 ; \mathrm{p}<0.005)$ and ATP/ADP ratio $(1.0 \pm 0.1, \mathrm{n}=3$ vs. $1.9 \pm 0.3, \mathrm{n}=2 ; \mathrm{p}<0.04)$ induced by $10 \mathrm{mM} \mathrm{KIC.} 10 \mathrm{mM}$ SSA also increased islet ATP content both in the absence (+93.5\%) and presence $(+45.0 \%)$ of 3 $\mathrm{mM}$ glucose (Fig. 2) and elevated the corresponding ATP/ADP ratios by 84 and $26 \%$, 
respectively. Islet pre-treatment with $1 \mathrm{mM}$ gabaculin for 45 minutes (as in the perifusion experiments shown in Figure 6B), decreased the ATP content of islets incubated with $10 \mathrm{mM}$ SSA and the GABA-T inhibitor during the 30 following minutes $(2.7 \pm 0.2, \mathrm{n}=3$ vs. $3.3 \pm 0.08 \mathrm{pmol} /$ islet, $\mathrm{n}=3 ; \mathrm{p}<0.047)$. MAD suppressed the elevation of islet ATP levels by $10 \mathrm{mM} \mathrm{SSA}$ at $20(4.1 \pm 0.05, \mathrm{n}=3$ vs. $4.6 \pm 0.1 \mathrm{pmol} /$ islet, $\mathrm{n}=7 ; \mathrm{p}<0.035)$ and $40 \mathrm{mM}(3.2 \pm 0.2, \mathrm{n}=5$ vs. $4.6 \pm 0.1 \mathrm{pmol} /$ islet, $\mathrm{n}=7 ; \mathrm{p}<$ $0.00003)$. MAD was more effective reducing islet ATP content at $20 \mathrm{mM}$ glucose: a significant decrease was already obtained at $10 \mathrm{mM}$ (data not shown). This is probably due to a stronger competition between MAD and the succinic acid generated by SSA as compared with $20 \mathrm{mM}$ glucose. $2 \mathrm{mM}$ Fluoroacetate, an aconitase inhibitor, also suppressed the elevation of islet ATP content by $10 \mathrm{mM} \mathrm{SSA}(3.1 \pm 0.1, \mathrm{n}=4$ vs. $4.6 \pm$ $0.1 \mathrm{pmol} /$ islet, $\mathrm{n}=7 ; \mathrm{p}<0.00003)$, suggesting that the generated succinic acid may be converted into acetyl-CoA (via the malate / pyruvate cycle) and further metabolized in the citric acid cycle.

\section{Islet perifusion experiments}

Perifused rat islets responded with a biphasic release of insulin after stimulation with 20 $\mathrm{mM}$ glucose (Figure 3A). Gabaculine $(1 \mathrm{mM})$, when included during the pre-perifusion at $5 \mathrm{mM}$ glucose for 45 minutes as well as the subsequent stimulation by $20 \mathrm{mM}$ glucose, significantly reduced both the first phase $(13.3 \pm 2.0, n=5$ vs. $25.5 \pm 4.0 \mathrm{ng} / 40$ islets $\mathrm{x} 10 \mathrm{~min}, \mathrm{n}=5 ; \mathrm{p}<0.025$ ) and the second phase (initial 20 minutes, 65.1 \pm 6.5 , $\mathrm{n}=5$ vs. $95.3 \pm 10.4 \mathrm{ng} / 40$ islets $\times 20 \mathrm{~min}, \mathrm{n}=5 ; \mathrm{p}<0.031)$ of the response to glucose elevation (Figure 3A).

Gln is the most abundant $\alpha$-amino acid in the blood and the main precursor for the synthesis of GABA. GABA reaches a close to maximal intracellular content at physiological Gln concentrations (0.5 to $1.0 \mathrm{mM}$ ) (Fig. 1) [19]. Gln does not stimulate insulin secretion, nor does it potentiate the secretory response to glucose, as deduced from the statistical comparisons among perifusions in Figure 3. However, it is conceivable that in its presence the contribution of "GABA-shunt" metabolism to total islet metabolism would be higher when the islets were stimulated by glucose. At $1 \mathrm{mM}$ Gln, islets treated with only $0.25 \mathrm{mM}$ gabaculine during pre-perifusion for 45 minutes showed a trend to decreased second phase insulin secretion $(93.0 \pm 10.2, n=6$ vs. 124.6 $\pm 10.7 \mathrm{ng} / 40$ islets $\times 20 \mathrm{~min}, \mathrm{n}=7$; $\mathrm{p}=0.057$ ) when subsequently stimulated with $20 \mathrm{mM}$ glucose in the presence of the inhibitor: as indicated in Figure 3B, there were statistically significant differences between the secretory rate of control and treated islets along several time points of the second phase of secretion. At a supraphysiological Gln concentration of $10 \mathrm{mM}$, a similar treatment with $1 \mathrm{mM}$ gabaculin induced significant decreases of both the first $(22.0 \pm 3.2, \mathrm{n}=6$ vs. $31.2 \pm 2.1 \mathrm{ng} / 40$ islets $\mathrm{x} 10$ $\min , \mathrm{n}=6 ; \mathrm{p}<0.037)$ and second phase of insulin release $(50.0 \pm 6.2, \mathrm{n}=5$ vs. $84.0 \pm 5.3$ ng $/ 40$ islets $\times 20$ min, $n=6 ; p<0.002$ ) (Fig. 3C).

Pre-perifusion of islets with $5 \mathrm{mM}$ glucose and $20 \mathrm{mM}$ allylglycine, a GAD inhibitor precursor, during the 45 minutes preceding the stimulation with $20 \mathrm{mM}$ glucose, suppressed the total amount of insulin released during the stimulation period by $35 \%$ $(62.8 \pm 12.9, \mathrm{n}=4$ vs. $97.0 \pm 8.0 \mathrm{ng} / 40$ islets $\times 30 \mathrm{~min}, \mathrm{n}=6 ; \mathrm{p}<0.05)$ (online Fig. 2$)$. No significant effect of $20 \mathrm{mM}$ allylglycine was recorded during islet stimulation with 7 $\mathrm{mM}$ glucose (data not shown).

Islet depolarization with high $\mathrm{KCl}(70 \mathrm{mM})$ induced a monophasic insulin secretion in islets perifused with $5 \mathrm{mM}$ glucose (data not shown). It also stimulates GABA release and produces a secondary decrease of the amine content: Under this condition, the 
insulin secretory response to oxo-4-methylpentanoic acid (KIC) is strongly suppressed [25]. The stimulation of insulin secretion by $20 \mathrm{mM}$ glucose was also decreased in the presence of $70 \mathrm{mM} \mathrm{KCl}$, although not as intensively as the response to $\mathrm{KIC}$, and affected mainly the second phase of release $(58.3 \pm 9.1, \mathrm{n}=5 \mathrm{vs} .89 .0 \pm 6.4 \mathrm{ng} / 40$ islets x $20 \min , \mathrm{n}=12 ; \mathrm{p}<0.03$ ) (Figure 4A).

Similarly, $70 \mathrm{mM} \mathrm{KCl}$ suppressed the second phase of the islet secretory response to 20 $\mathrm{mM}$ glucose in presence of $10 \mathrm{mM}$ Gln $(49.4 \pm 11.8, \mathrm{n}=6 \mathrm{vs} .94 .5 \pm 14.7 \mathrm{ng} / 40$ islets $\mathrm{x}$ $20 \mathrm{~min}, \mathrm{n}=4 ; \mathrm{p}<0.05$ ) (Figure 4B). Islet pre-exposure to $5 \mathrm{mM}$ glucose plus $70 \mathrm{mM}$ $\mathrm{KCl}$ for 45 minutes induced a stronger suppression of both the first $(7.3 \pm 1.2, n=5 \mathrm{vs}$. $23.6 \pm 4.5 \mathrm{ng} / 40$ islets $\times 10 \mathrm{~min}, \mathrm{n}=6 ; \mathrm{p}<0.01)$ and the second phase $(40.8 \pm 6.7, \mathrm{n}=5$ vs. $80.6 \pm 13.8 \mathrm{ng} / 40$ islets $\times 20 \mathrm{~min}, \mathrm{n}=6 ; \mathrm{p}<0.04$ ) of the insulin response to $20 \mathrm{mM}$ glucose (Figure 4C). Insulin content of islets pre-incubated for 1 hour at $5 \mathrm{mM}$ glucose plus $70 \mathrm{mM} \mathrm{KCl}$ and a second hour at $20 \mathrm{mM}$ glucose was the same as in the controls, incubated at $5 \mathrm{mM}$ glucose during the first hour and at $20 \mathrm{mM}$ glucose during the second hour $(643.3 \pm 59.9, \mathrm{n}=6$ vs. $597.0 \pm 42.9 \mathrm{ng}$ insulin/islet, $\mathrm{n}=6$; N.S. $)$. Addition of $10 \mathrm{mM}$ L-glutamine together with $20 \mathrm{mM}$ glucose did not reverse KCl-induced inhibition (data not shown).

$10 \mathrm{mM}$ SSA elicited biphasic insulin secretion in the presence of a basal $(5 \mathrm{mM})$ glucose concentration that was similar in magnitude to that triggered by $20 \mathrm{mM}$ glucose (Figure 5A). The combination of 5 or $10 \mathrm{mM}$ SSA together with $20 \mathrm{mM}$ glucose did not modify the magnitude, nor the pattern, of the insulin response induced by glucose alone (Figure 5B). In the absence of glucose, $10 \mathrm{mM}$ SSA induced a much lower first (10.8 \pm $1.6, \mathrm{n}=12$ vs. $19.2 \pm 2.7 \mathrm{ng} / 40$ islets $\mathrm{x} 10 \mathrm{~min}, \mathrm{n}=6, \mathrm{p}<0.01)$ and second phase of insulin secretion $(48.4 \pm 3.7, n=12$ vs. $64.0 \pm 5.6 \mathrm{ng} / 40$ islets $\times 20 \mathrm{~min}, \mathrm{n}=6 ; \mathrm{p}<0.03)$ than in presence of $5 \mathrm{mM}$ glucose (compare Figures $5 \mathrm{~A}$ and $6 \mathrm{~A}$ ). Biphasic insulin secretion induced by $10 \mathrm{mM}$ SSA was unaffected by the presence of Gln (Figure 6C). Pre-perifusion with $1 \mathrm{mM}$ gabaculine for 45 minutes suppressed the second phase of insulin secretion stimulated by $10 \mathrm{mM} \mathrm{SSA}$ both in the absence $(32.6 \pm 2.5, \mathrm{n}=6$ vs. $50.9 \pm 5.6 \mathrm{ng} / 40$ islets $\times 10 \mathrm{~min}, \mathrm{n}=6 ; \mathrm{p}<0.01)$ and presence of $10 \mathrm{mM}$ L-glutamine $(30.6 \pm 6.1, \mathrm{n}=5$ vs. $61.1 \pm 8.7 \mathrm{ng} / 40$ islets $\mathrm{x} 10 \mathrm{~min}, \mathrm{n}=5 ; \mathrm{p}<0.02)$ (Figures $6 \mathrm{~B}$ and $6 \mathrm{C}$, respectively). $\beta$-Cell depolarization with $70 \mathrm{mM} \mathrm{KCl}$ did not modify the secretory response to $10 \mathrm{mM}$ SSA alone in perifused islets (online Fig. 4).

\section{SSA effects on $\beta$-cell membrane potential}

Addition of SSA $(10 \mathrm{mM}$, at $1 \mathrm{mM}$ extracellular glucose) to the extracellular medium depolarized isolated $\beta$-cells and induced action potential firing (Fig. 7A and B). This was accompanied by a reduction of membrane currents through ATP-sensitive $\mathrm{K}^{+}$ channels $\left(\mathrm{K}_{\mathrm{ATP}}\right.$ channels; Fig. $\left.7 \mathrm{C}\right)$. The ability of SSA to depolarize $\beta$-cells and inhibit $\mathrm{K}_{\text {ATP }}$ channels was preserved in cells that had been incubated with gabaculine $(1 \mathrm{mM})$ in the culture medium for $1 \mathrm{~h}$ prior to the experiments (data not shown). Increasing the extracellular glucose concentration from 1 to 7 , or $20 \mathrm{mM}$, depolarized $\beta$-cells in a concentration-dependent manner. This effect of glucose was unaltered when cells had been pre-incubated with gabaculine $(1 \mathrm{mM}, 1-2 \mathrm{~h})$ prior to the experiments (data not shown). Islet expression profile of the genes of some citric acid cycle and "GABA-shunt"
enzymes and their activities 
At the mRNA level, 2-OG-dh was the least expressed among the six genes studied, calculated as percentage of D-glyceraldehyde dehydrogenase expression which was used as the reference, housekeeping gene (online Fig. 3). Very similar results were obtained using $18 \mathrm{~S}$ rRNA as the reference gene (data not shown). The messages for GAD65 and GABA-T were 6-fold more abundant than that of 2-OG-dh. The "GABAshunt" enzymes catalyzing SSA oxidation (SSA-dh) and reduction (SSA-R) were expressed at slightly higher levels than 2-OG-dh. The citric acid cycle enzyme accepting the final product of the "GABA-shunt", Succ-dh, was expressed 3-fold more intensively than the 2-OG-dh gene. This expression profile is similar to that of rat cerebellum but very different from liver tissue which does not express GAD65 (data not shown). A comparative study of 2-OG-dh and GABA-T activities in islet homogenates showed that the former was several fold lower than the latter $(2.5 \pm 0.1, n=4$ vs. $7.0 \pm$ $1.6 \mathrm{nmol} \mathrm{NADH} / \mathrm{min}$. $\mathrm{x} \mathrm{mg}$. protein, $\mathrm{n}=4$; $\mathrm{p}<0.03$ ).

\section{DISCUSSION}

High glucose $(20 \mathrm{mM})$ significantly diminished the islet GABA content at a physiological L-glutamine concentration $(0.5 \mathrm{mM})$ without modifying the content of any other $\alpha$-amino acid and it decreased not only GABA but also Glu and Asp release. Overall analysis of the data at the $\operatorname{Gln}(0,0.5$ and $10.0 \mathrm{mM})$ and glucose concentrations $(0$ and $20 \mathrm{mM})$ used showed a positive correlation between islet GABA release and content, suggesting that the free (exchangeable) fraction of GABA is proportional to the content. A study of separate correlations revealed that the slope was steeper at 0 than 20 $\mathrm{mM}$ glucose (data not shown), indicating a higher usage and less availability of free GABA at high glucose. The stable islet content of Asp and Glu between 0 and $20 \mathrm{mM}$ glucose probably reflects metabolic changes secondary to an increased succinic acid production in the "GABA shunt" and hence of oxaloacetate which is then transaminated to Asp. The Glu content may be maintained by increased citric acid cycle provision of 2-oxoglutarate at $20 \mathrm{mM}$ glucose. In fact, malonic acid dimethyl ester, a permeable succinic acid dehydrogenase inhibitor [32], decreased islet Asp content without modifying that of GABA or Glu. Moreover, gabaculine inhibition of GABA metabolism significantly decreased Asp content.

It can be reasonably argued that, given that glucose decreases GABA release, the suppression of its content can only be attributable to its increased metabolism via the "GABA shunt". This effect was dependent on glucose metabolism in the $\beta$-cells as inhibition of the latter by D-mannoheptulose blocked the reduction of islet GABA content. This confirms the previously described ability of D-mannoheptulose to suppress glucose-induced decrease of islet GABA content and release in cultured human and rat $\beta$-cells at $2 \mathrm{mM}$ L-glutamine $[33,21]$. Several findings suggest that glucose promotion of islet GABA metabolism relies on citric acid supply of 2oxoglutarate that transaminates with GABA to produce Glu and SSA in the first reaction of the "GABA shunt": 1. The GABA transaminase inhibitors gabaculine (this work) and $\gamma$-vinyl-GABA in [21] suppressed glucose-induced reduction of GABA content. 2. Addition of a permeable form of 2-oxoglutarate (its dimethyl ester) increased islet Glu but decreased islet GABA production above a certain concentration [19]. 3. KIC suppresses more strongly than glucose (even in the absence of L-glutamine) islet GABA content in a transamination dependent mechanism: Inhibition of either GABA-T with gabaculine or the branched-chain $\alpha$-keto acid transaminase (generating L-leucine 
and 2-oxoglutarate) with 4-methyl valeric acid, blocked GABA suppression in both cases as well as insulin secretion $[20,25]$.

In support of the involvement of islet GABA metabolism in the stimulation of insulin secretion, islet pre-treatment with $1 \mathrm{mM}$ gabaculine reduced (by 30 to almost 50\%) both phases of the insulin secretory response to $20 \mathrm{mM}$ glucose in the absence and presence of L-glutamine. Additionally, gabaculine diminished the glucose-induced elevation of islet ATP content and ATP/ADP ratio. Moreover, pre-exposure of islets to allylglycine, a GAD inhibitor precursor, also decreased the subsequent secretory response to $20 \mathrm{mM}$ glucose. These data may seem at odds with the failure of gabaculine to interfere with glucose-induced membrane depolarization of isolated $\beta$-cells. However, the ATP content of islets incubated with $20 \mathrm{mM}$ glucose plus $1 \mathrm{mM}$ gabaculine was higher than the content of islets incubated at $3 \mathrm{mM}$ glucose $(3.47 \pm 0.12, \mathrm{n}=5$, vs. $2.82 \pm 0.14$ $\mathrm{pmol} /$ islet, $\mathrm{n}=18 ; \mathrm{p}<0.03$ ). It has previously been shown that the amplifying pathway of glucose stimulation has a higher $\mathrm{K}_{\mathrm{m}}$ for glucose than the triggering pathway [34]. It is thus possible that the smaller increase in ATP attained with gabaculine is sufficient to close $\mathrm{K}_{\mathrm{ATP}}$ channels but not to fully support the amplifying pathway of glucose-induced insulin secretion.

Our data confirm a previous report showing that $\gamma$-vinil-GABA (another GABA-T inihibitor) tends to decrease glucose-induced secretion and significantly (by $40 \%$ ) reduces 3-phenylpyruvate stimulated insulin secretion in the perfused rat pancreas [24]. The authors concluded their results were compatible with the hypothesis that GABA metabolism via the GABA shunt might have a role in insulin secretion. At variance with this and our own interpretation, the authors of a recent report [21] suggested that $\gamma$ vinyl-GABA decreases glucose-stimulated insulin secretion of 24 hours cultured rat $\beta$ cells independently of their modification of GABA metabolism, as the effect was observed only at an inhibitor concentration $(>7 \mathrm{mM})$ well above the concentration range $(0.3$ and $1.6 \mathrm{mM})$ required to increase cellular GABA content. However, in our freshly isolated rat islet preparation, an inhibition of insulin secretion was observed at 0.25 and $1.0 \mathrm{mM}$ gabaculine after 45 to 60 minutes of pre-exposure to the drug (see Figure 6). Furthermore, we have previously demonstrated that the simultaneous perifusion of $10 \mathrm{mM}$ KIC together with $0.25 \mathrm{mM}$ gabaculine (without previous exposure to the inhibitor) significantly reduced the magnitude of the biphasic response to the $\alpha$-keto acid and elevated the islet GABA content (19). The discrepancy between Wang et al. and our own results might be attributable to the different preparations used (24 hours cultured rat $\beta$-cells versus the perfused pancreas and freshly isolated rat islets). A role for GABA metabolism in GSIS is further supported by the inhibitory effect of $70 \mathrm{mM} \mathrm{KCl}$ as this treatment is known to deplete intracellular GABA and to strongly reduce KIC-induced insulin secretion [25]. However, the mechanism of GABA release from $\beta$-cells must be further explored before an unambiguous interpretation of the data can be made.

The stimulation of insulin secretion by SSA, together with its effects on islet adenine nucleotides, constitutes strong evidence in support of the "GABA-shunt" as an alternative or complementary pathway of glucose metabolism. This is corroborated by the ability of SSA to depolarize $\beta$-cells through a reduction of the ATP-sensitive $\mathrm{K}^{+}$current. SSA is converted to GABA by reversion of GABA-T catalyzed reaction that also generates 2-oxoglutarate and it is probably also converted to succinic acid by SSA$\mathrm{dh}$. Both succinic acid and 2-oxoglutarate can be metabolized in the citric acid cycle and 
contribute to ATP generation. In support of this interpretation, GABA-T inhibition by gabaculine partially suppressed the second phase of the secretory response to SSA. Even though the inhibitor failed to modify SSA-induced membrane depolarization of isolated $\beta$-cells, succinic acid production might contribute to ATP generation during the second phase of release. SSA metabolism by the same mitochondrial pathways as glucose explains why the two secretagogues did not show any synergism.

The gene expression profile, as well as the study of the corresponding enzymatic activities, showed that GABA-T is almost three-fold more abundant than 2-OG-dh in islet homogenates. Both enzymes have similar $\mathrm{Km}$ values for their common substrate 2oxoglutarate. Therefore, it seems reasonable to assume that 2-oxoglutarate generated in the citric acid cycle is preferentially metabolized in the "GABA-shunt" to succinic acid rather than being decarboxylated in the cycle by 2-OG-dh. Moreover, 2-OG-dh is subject to regulation by the NADH / $\mathrm{NAD}^{+}$and ATP/ADP ratios (35) and has long been considered as a rate limiting step in the citric acid cycle (36). Inhibition of 2-OG-dh by an increased ATP/ADP ratio at high glucose concentrations might increase the availability of 2-oxoglutarate for GABA transaminase which would then bypass the citric acid cycle bottleneck via the "GABA shunt" to succinic acid. Therefore, the metabolic flow of glucose in the "GABA shunt" might increase with its concentration. This might explain the partial dependence of glucose-induced insulin secretion on "GABA-shunt" metabolism as previously suggested [24].

\section{FUNDING}

This work was supported by grants from Instituto de Salud Carlos III (RGDM G03/212 and PI-061744), Madrid (Spain), the MRC and Wellcome Trust. Inés Hernández-Fisac was supported by a four-year fellowship of the Ministery of Education and Science, Madrid, Spain; J. Pizarro-Delgado by a 14-month fellowship from Instituto de Salud Carlos III (RGDM G03/212), Madrid (Spain).

\section{REFERENCES}

1. Gerber J.C. and Hare T.A. (1979) Gamma-aminobutyric acid in peripheral tissue with emphasis on the endocrine pancreas. Presence in two species and reduction by streptozotocin. Diabetes 28: 1073-1076

2. Taniguchi H., Okada Y., Seguchi H., Shimada C., Seki M., Tsutou A. and Baba S. (1979) High concentration of gamma-aminobutyric acid in pancreatic beta cells. Diabetes 28: 629-633

3. Vincent S.R., Hồkfelt T., Wu J.-Y., Elde R.P., Morgan L.M. and Kimmel J.R. (1983) Immunohistochemical studies of the GABA system in the pancreas. Neuroendocrinol. 36: 197-204

4. Michalik M., Nelson J. and Erecinska M. (1993) GABA production in rat islets of Langerhans. Diabetes 42: 1506-1513

5. Sánchez-Soto M.C., Larrieta M.E., Vidaltamayo R. and Hiriart M. (1999) Heterogeneity in glutamic acid decarboxylase expression among single rat pancreatic beta cells. Diabetologia 42: 1086-1092

6. Kim J., Richter W., Aanstoot H.-J., Shi Y., Fu Q., Rajote R., Warnock G. and Baekkeskov S. (1993) Differential expression of $\mathrm{GAD}_{65}$ and $\mathrm{GAD}_{67}$ in human, rat, and mouse pancreatic islets. Diabetes 42: 1799-1808

7. González de Pliego M., Aguirre-Benítez E., Sánchez-Soto M.C., Larrieta M.E., Velásquez-Carranza A., Vidaltamayo R., Meza-Mora M., Zepeda-Rodríguez A., 
Hernández-Falcón J. and Hiriart M. (2001) Ultrastructural changes in pancreatic beta cells treated with NGF and dbcAMP. Cell Tiss.Res. 305: 365-378

8. Gammelsaeter R., Froyland M., Aragón C., Danbolt N.C., Fortin D., StormMathisen J., Davanger S. and Gundersen V. (2004) Glycine, GABA and their transporters in pancreatic islets of Langerhans: evidence for a paracrine transmitter interplay. J. Cell Sci.117: 3749-3758

9. Braun M., Wendt A., Karanauskaite J., Galvanovskis J., Clark A., MacDonald P.E. and Rorsman P. (2007) Corelease and differential exit via the fusion pore of GABA, serotonin, and ATP from LDCV in rat pancreatic beta cells. J. Gen. Physiol. 129:221-231

10. Thomas-Reetz A., Hell J.W., During M J, Walch-Solimena C., Jahn R.and De Camilli P (1993) A gamma-aminobutyric acid transporter driven by a proton pump is present in synaptic-like microvesicles of pancreatic beta cells. Proc. Natl. Acad. Sci. U S A 90: 5317-5321

11. Suckow A. T., Sweet I. R., Van Yserloo B., Rutledge E. A., Hall T. R., Waldrop M. and Chessler S. D. (2006) Identification and characterization of a novel isoform of the vesicular gamma-aminobutyric acid transporter with glucoseregulated expression in rat islets. J. Mol. Endocrinol. 36:187-199

12. Smismans A., Schuit F. and Pipeleers D. (1997) Nutrient regulation of gammaaminobutyric acid release from islet beta cells. Diabetologia 40:1411-1415

13. Rorsman P., Berggren P.-O., Bokvist K., Ericson H., Möhler H., Östenson G.-C. and Smith P. A. (1989) Glucose-inhibition of glucagons secretion involves activation of $\mathrm{GABA}_{\mathrm{A}}$-receptor chloride channels. Nature 341: 233-236

14. Gaskins H. R., Baldeón M. E., Selassie L. and Beverly J. L. (1995) Glucose modulates $\gamma$-aminobutyric acid release from the pancreatic $\beta$ TC6 cell line. J. Biol. Chem. 270: 30286-30289

15. Wendt A., Birnir B., Buschard K., Gromada J., Salehi A., Sewing S., Rorsman P. and Braun M. (2004) Glucose inhibition of glucagon secretion from rat $\alpha-$ cells is mediated by GABA released from neighboring $\beta$-cells. Diabetes 53: 1038-1045

16. Braun M., Wendt A., Buschard K., Salehi A., Sewing S., Gromada J. and Rorsman P. (2004) $\mathrm{GABA}_{\mathrm{B}}$ receptor activation inhibits exocytosis in rat pancreatic $\beta$-cells by $G$-protein-dependent activation of calcineurin. J. Physiol. 559: $397-402$

17. Brice L., Varadi A., Ashcroft S. J. H. and Molnar E. (2002) Metabotropic glutamate and $\mathrm{GABA}_{\mathrm{B}}$ receptors contribute to the modulation of glucosestimulated insulin secretion in pancreatic beta cells. Diabetologia 45: 242-252

18. Sörenson R.L., Garry D.G. and Brelje T.C. (1991) Structural and functional considerations of GABA in islet of Langerhans, $\beta$-cells and nerves. Diabetes 40: $1365-1374$

19. Fernández-Pascual S., Mukala-Nsengu-Tshibangu A., Martín del Río R. and Tamarit-Rodriguez J. (2004) Conversion into GABA ( $\gamma$-aminobutyric acid) may reduce the capacity of L-glutamine as an insulin secretagogue. Biochem. J. 379: 721-729

20. Hernández-Fisac I., Fernández-Pascual S., Ortsäter H., Pizarro-Delgado J., Martín-del-Río R., Bergsten P. and Tamarit-Rodriguez J. (2006) Oxo-4methylpentanoic acid directs the metabolism of GABA into the Krebs cycle in rat pancreatic islets. Biochem. J. 400: 81-89

21. Wang C., Kerckhofs K., Van-de-Casteele M., Smolders I., Pipeleers D. and Ling Z. (2006) Glucose inhibits GABA release by pancreatic $\beta$-cells though an 
increase in GABA shunt activity. Am. J. Physiol. Endocrinol. Metab. 290: E494E499

22. Braun M., Ramracheya R., Martin Bengtsson M., Clark A., Walker N., Johnson P.R. and Rorsman P. (2010) GABA is an autocrine excitatory transmitter in human pancreatic beta-cells. Diabetes, in press

23. Shi Y., Kanaani J., Menard-Rose V., Ma Y. H., Chang P.-Y., Hanahan D., Tobin A., Grodsky G. and Baekkeskov S. (2000) Increased expression of GAD65 and GABA in pancreatic $\beta$-cells impairs first-phase insulin secretion. Am. J. Physiol. Endocrinol. Metab. 279: E684-E694

24. Rubí B., Ishihara H., Hegardt F. G., Wollheim C. B. and Maechler P. (2001) GAD65-mediated glutamate decarboxylation reduces glucose-stimulated insulin secretion in pancreatic beta cells. J. Biol. Chem. 276: 36391-36396

25. Pizarro-Delgado J., Hernández-Fisac I., Martín-del-Río R. and TamaritRodriguez J. (2009) Branched-chain 2-oxo-acids transamination increases GABA-shunt metabolism and insulin secretion in isolated islets. Biochem. J. 419: $359-368$

26. Herbert V., Lau K., Gottlieb C. and Bleicher S. J. (1965) Coated charcoal immunoassay of insulin. J. Clin. Endorinol. Metab. 25: 1375-1384

27. Jones, B.N., Paabo, S. and Stein, S. (1981) Amino acid analysis and enzymatic sequence determination of peptides by an improved o-phtalaldialdehyde precolumn labeling procedure. J. Liquid Chromatogr. 4: 565-586

28. Lowry O. H., Rosenbrough N. J., Farr A. L. and Randall R. J. (1951) Protein measurement with the Folin phenol reagent. J. Biol. Chem. 193: 265-275

29. Lenzen S., Tiedge M. and Panten U. (1987) Glucokinase in pancreatic $\beta$-cells and its inhibition by alloxan. Acta Endocrinol. (Copenh.) 5: 21-29

30. Fu M. and Silverman R.B. (1999) Isolation and characterization of the product of inactivation of $\gamma$-aminobutyric acid aminotransferase by gabaculine. Bioorg. Med. Chem. 7: 1581-1590

31. Reingold D.F. and Orlowski M. (1979) Inhibition of brain glutamate decarboxylase by 2-keto-4-pentenoic acid, a metabolite of allylglycine. J. Neurochem. 32: 907-913

32. Mukala-Nsengu A., Fernández-Pascual S., Martín F., Martín-del-Río R. and Tamarit-Rodríguez J. (2004) Similar effects of succinic acid dimethyl ester and glucose on islet calcium oscillations and insulin release. Biochem.Pharmacol. 67: 981-988

33. Winnock F., Ling Z., De-Proft R., Dejonghe S., Schuit F., Gorus F. and Pipeleers D. (2002) Correlation between GABA release from rat islet $\beta$-cells and their metabolic state. Am. J. Physiol. Endocrinol. Metab. 282: E937-E942

34. Henquin J. C. (2009) Regulation of insulin secretion: a matter of phase control and amplitude modulation. Diabetologia 52: 739-751

35. Heckert L. L., Butler M. H., Reimers J. M., Albe K. R and Wright B.E. (1989) Purification and characterization of the 2-oxoglutarate dehydrogenase complex from dicyostelium discoideum. J. Gen. Microbiol. 135: 155-161

36. Lai J. C. K., Walsh J. M., Dennis S. C. and Claerk J. B. (1977) Synaptic and non-synaptic mitochondria from rat brain: isolation and characterization. J. Neurochem. 22: 625-631

\section{LEGENDS TO FIGURES}


Figure 1. Effect of $20 \mathrm{mM}$ glucose on islet Glu $(A)$, Asp $(B)$ and GABA $(C)$ content (isl) and release (med) after pre-incubation with the indicated Gln concentrations. (D) Relationship between GABA content and GABA release.

Three groups, each of 30 islets, were pre-incubated for 1 hour at $37^{\circ} \mathrm{C}$ with different Gln concentrations $(0,0.5$, or $10 \mathrm{mM}$, as indicated in each graph. After discarding the medium and washing the islets twice with saline, they were further incubated for a second hour in the absence of substrates (G0) or in the presence of $20 \mathrm{mM}$ glucose (G20). At the end of incubation, the medium (med) and islets (isl) were separated for the measurement of their respective content of amino acids. The symbols represent mean values $\pm \mathrm{SE}$ of 7-8 different experiments. Each value was statistically compared with its corresponding control obtained in the absence of Gln during the pre-incubation phase $(* \mathrm{p}<0.025, \dagger \mathrm{p}<0.01,+\mathrm{p}<0.001)$. Comparisons between 0 and $20 \mathrm{mM}$ glucose are indicated by brackets.

Figure 2. Effect of 0,3 and $20 \mathrm{mM}$ glucose (G0, G3 and G20, respectively) and 10 $\mathrm{mM}$ semialdehyde succinic acid (SSA) on islet ATP levels and the ATP/ADP ratio. Modification of the adenine nucleotide profile at $20 \mathrm{mM}$ glucose by $1 \mathrm{mM}$ gabaculine (GABA-T inibitor).

Groups each of 25 islets were incubated for 1 hour at the conditions indicated in the figure. Incubations were stopped by freezing islets and medium and adenine nucleotides extracted with perchloric acid. After neutralization, ATP an ADP contents were determined with the luciferin/luciferase system, as described in detail in the Methods section.

Figure 3. Effect of gabaculine (GABA-T inhibitor) on the secretory response of perifused rat islets to $20 \mathrm{mM}$ glucose in the absence (A) and presence of 1 (B) and 10 $\mathrm{mM} \operatorname{Gln}(\mathrm{C})$.

Groups of 40 islets each, pre-perifused with $5 \mathrm{mM}$ glucose ( $\pm 1 \mathrm{mM}$ gabaculine) for 45 min, were stimulated for $30 \mathrm{~min}$ (between vertical broken lines) with $20 \mathrm{mM}$ glucose and the indicated additives. Pre-perifusion conditions were then re-established during the last $25 \mathrm{~min}$. Symbols represent means \pm S.E.M.

Figure 4. Modification of the insulin secretory response of rat perifused islets to $20 \mathrm{mM}$ glucose by the concomitant depolarization with $70 \mathrm{mM} \mathrm{KCl}$ in the absence (A) and presence of $10 \mathrm{mM} \mathrm{Gln}(\mathrm{B})$ or by a previous 45 minutes exposure to $70 \mathrm{mM} \mathrm{KCl}(\mathrm{C})$.

Groups of 40 islets each were pre-perifused with $5 \mathrm{mM}$ glucose alone for $45 \mathrm{~min}$ (A and B) or together with $70 \mathrm{mM} \mathrm{KCl}(\mathrm{C})$. They were then stimulated for $30 \mathrm{~min}$ (between vertical broken lines) with $20 \mathrm{mM}$ glucose alone (C) or together with $70 \mathrm{mM} \mathrm{KCl}$ (A and B). Pre-perifusion conditions were then re-established during the last $25 \mathrm{~min}$. Symbols represent means \pm S.E.M.

Figure 5. Insulinotropic capacity of semialdehyde succinic acid (SSA) in the presence of 5 (G5) and $20 \mathrm{mM}$ glucose (G20).

Groups of 40 islets each, pre-perifused with G5 alone for 45 min were then stimulated for $30 \mathrm{~min}$ (between vertical broken lines) with G20 alone or $5 \mathrm{mM}$ glucose plus 10 mM SSA (A). In (B) secretion was stimulated with G20 together with 5 and $10 \mathrm{mM}$ SSA. Pre-perifusion conditions were then re-established during the last $25 \mathrm{~min}$. Symbols represent means \pm S.E.M.

Figure 6. Effect of Gln and gabaculine (GABA-T inhibitor) on the stimulation of insulin secretion of perifused rat islets by $10 \mathrm{mM}$ SSA alone.

Groups of 40 islets each, pre-perifused without any substrate for $45 \mathrm{~min}$ were then stimulated for $30 \mathrm{~min}$ (between vertical broken lines) with $10 \mathrm{mM}$ SSA alone and together with $10 \mathrm{mM}$ Gln (A) or $1 \mathrm{mM}$ gabaculine (B). In (C), insulin secretion was stimulated by $10 \mathrm{mM}$ SSA plus $10 \mathrm{mM}$ Gln in the absence or presence of $1 \mathrm{mM}$ 
gabaculine. Pre-perifusion conditions were then re-established during the last $25 \mathrm{~min}$. Symbols represent means \pm S.E.M.

Figure 7. Modification of $\beta$-cell membrane potential by SSA

A) Recording of $\beta$-cell membrane potential at $1 \mathrm{mM}$ extracellular glucose. SSA (10 $\mathrm{mM}$ ) was applied as indicated by the bar. B) Average membrane potential of $\beta$-cells at 1 $\mathrm{mM}$ glucose before (control) and after addition of $10 \mathrm{mM} \mathrm{SSA}\left(n=5 ;{ }^{*} \mathrm{p}<0.01\right)$. C) $\beta$ cell $\mathrm{K}_{\mathrm{ATP}}$ current (measured by $10 \mathrm{mV}$ de- and hyper-polarizing pulses from $-70 \mathrm{mV}$ ) before and after application of $10 \mathrm{mM} \mathrm{SSA}\left(n=4 ;{ }^{*}<0.01\right)$. 


\section{FIGURES}
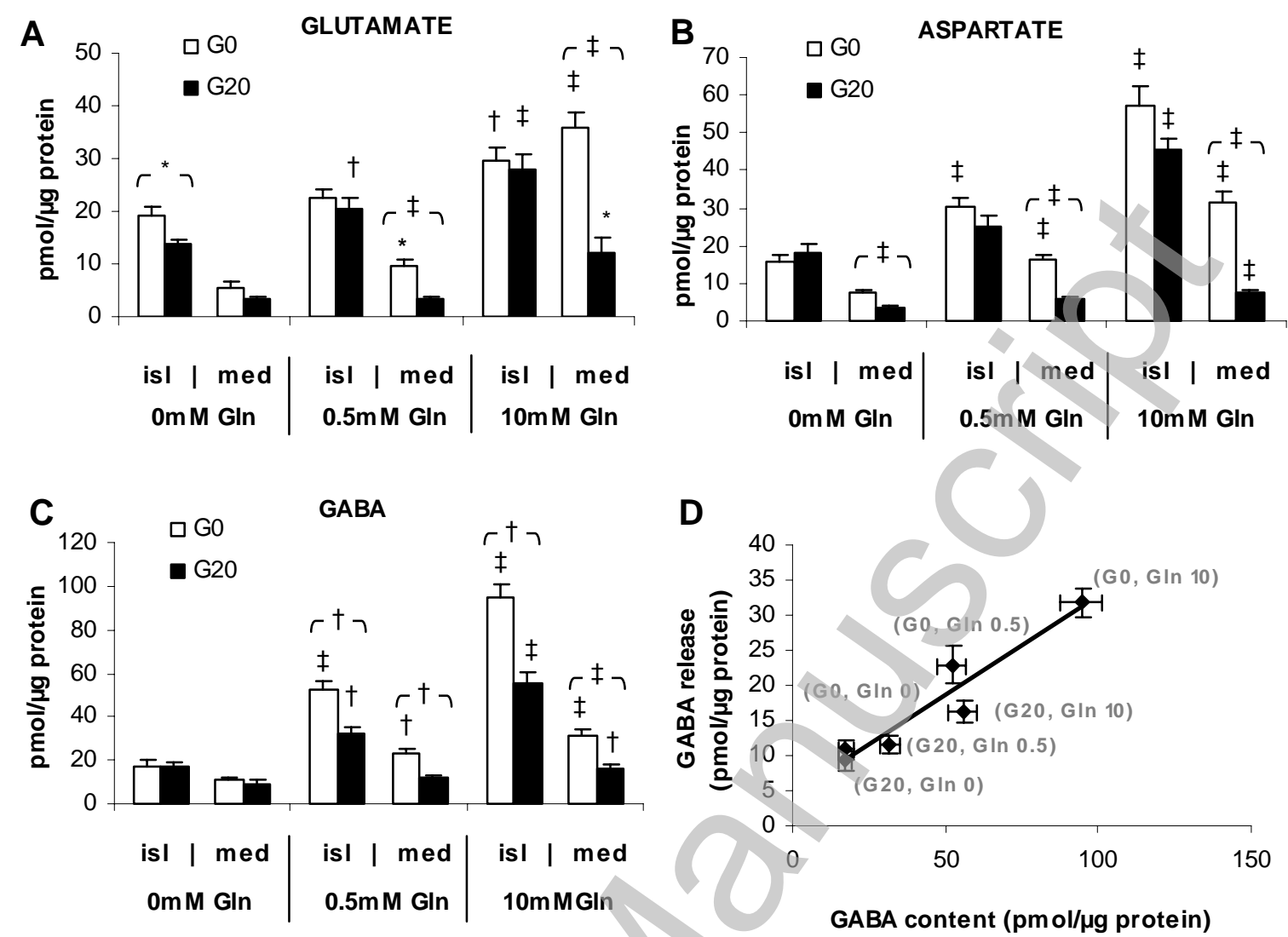

Figure 1
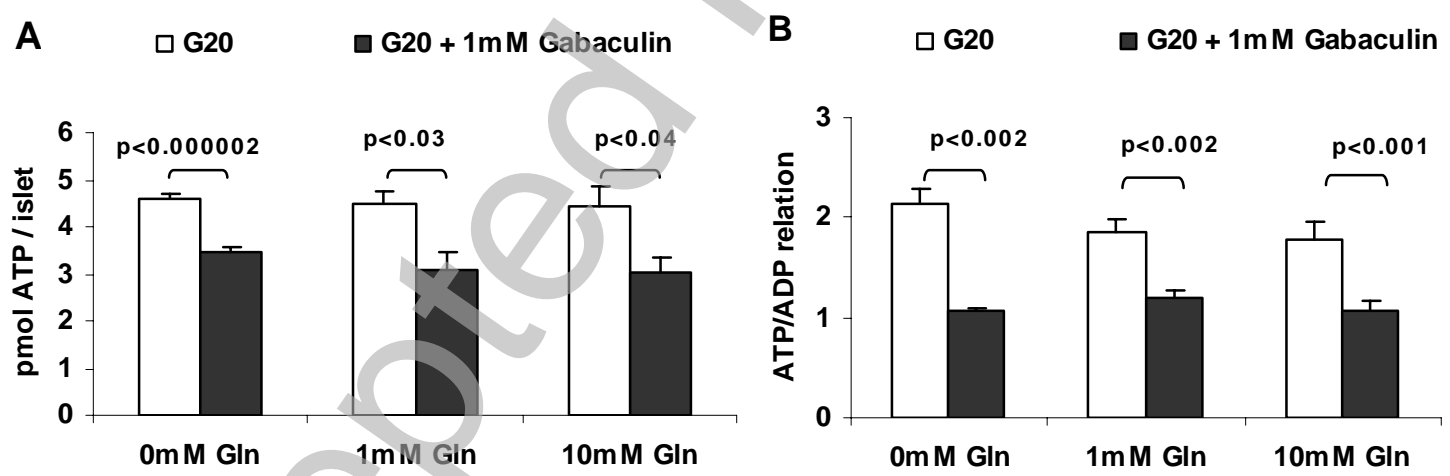

C $\square$ G0 $\square$ 10mM SSA $\square$ G3 $\square$ G3 + 10m M SSA

D $\square$ G0 $\square$ 10mM SSA $\square$ G3 $\square$ G3 + 10m M SSA
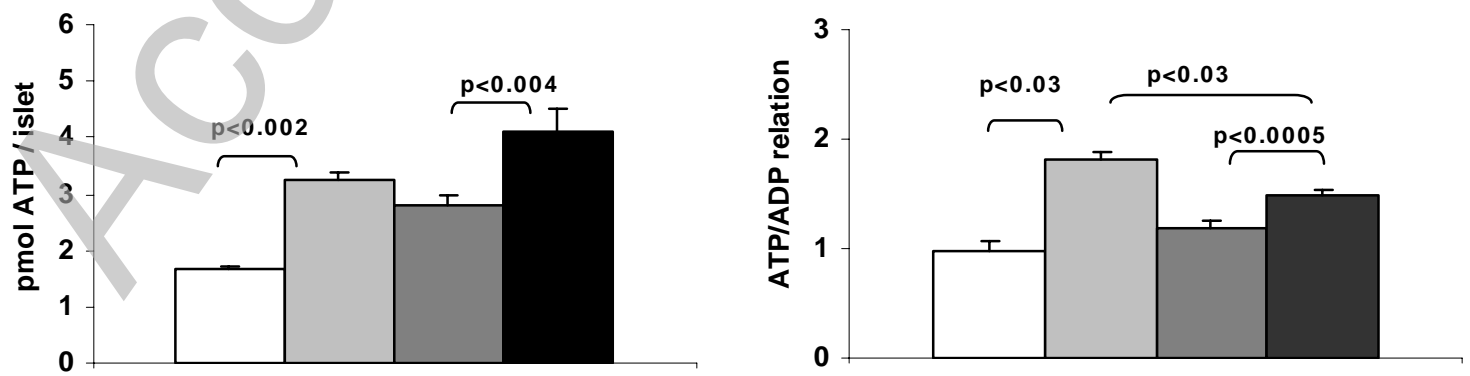

Figure 2

Licenced copy. Copying is not permitted, except with prior permission and as allowed by law.

(C) 2010 The Authors Journal compilation (c) 2010 Portland Press Limited 

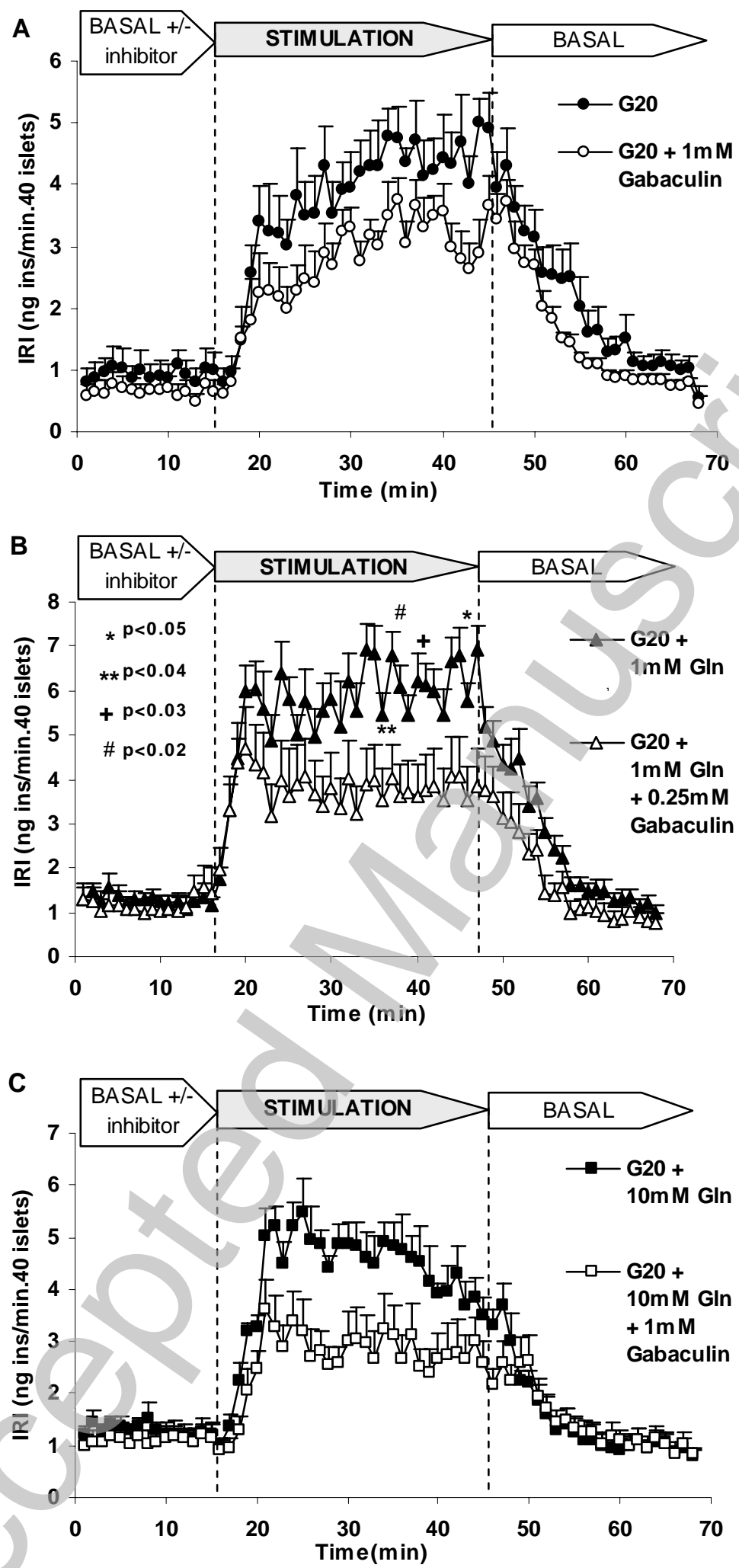

Figure 3 

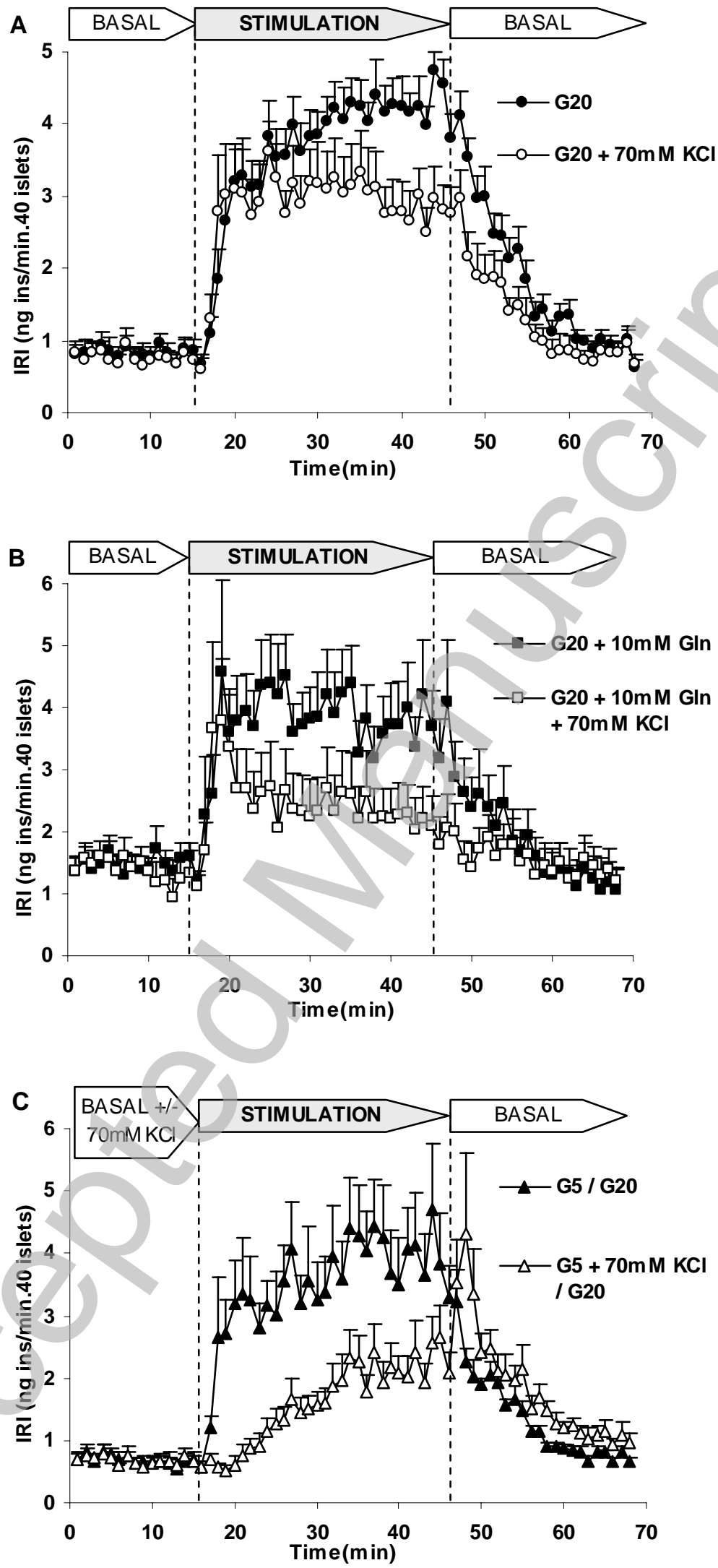

Figure 4 

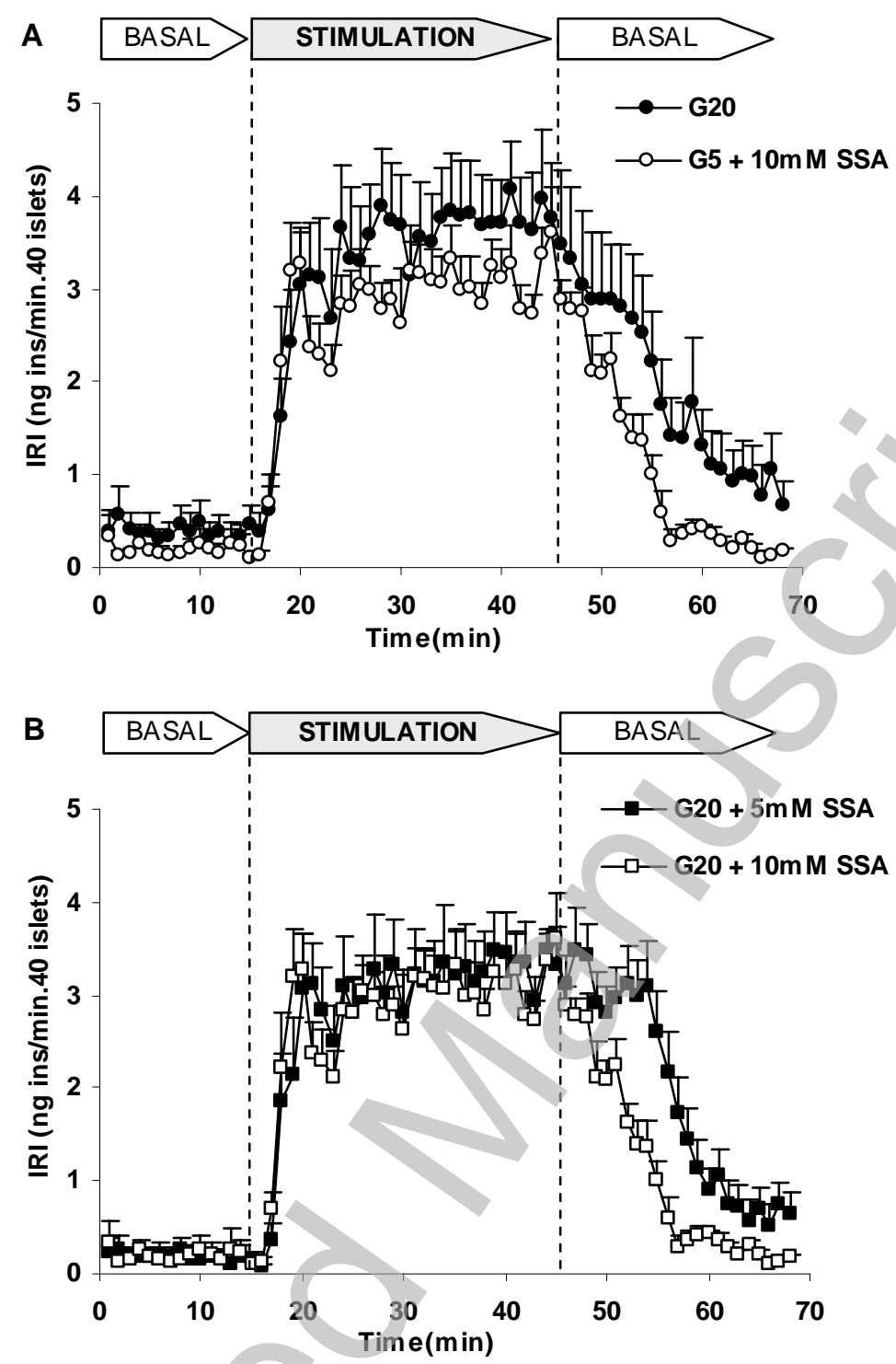

Figure 5 


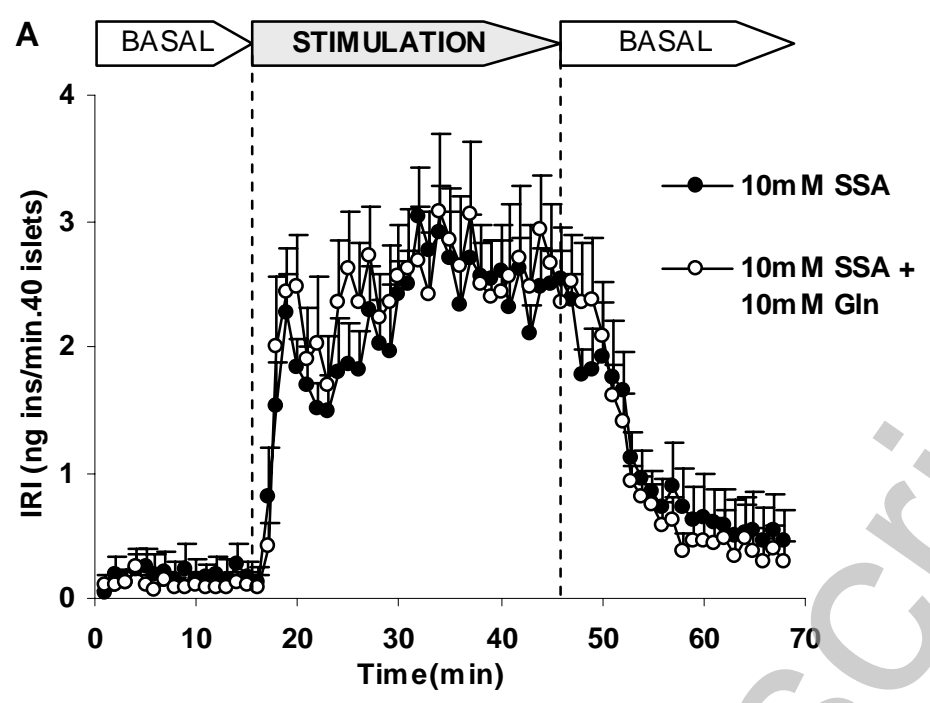

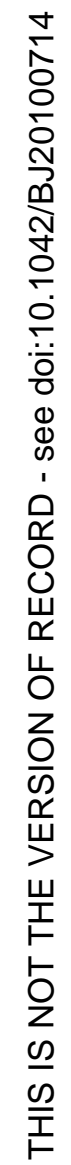
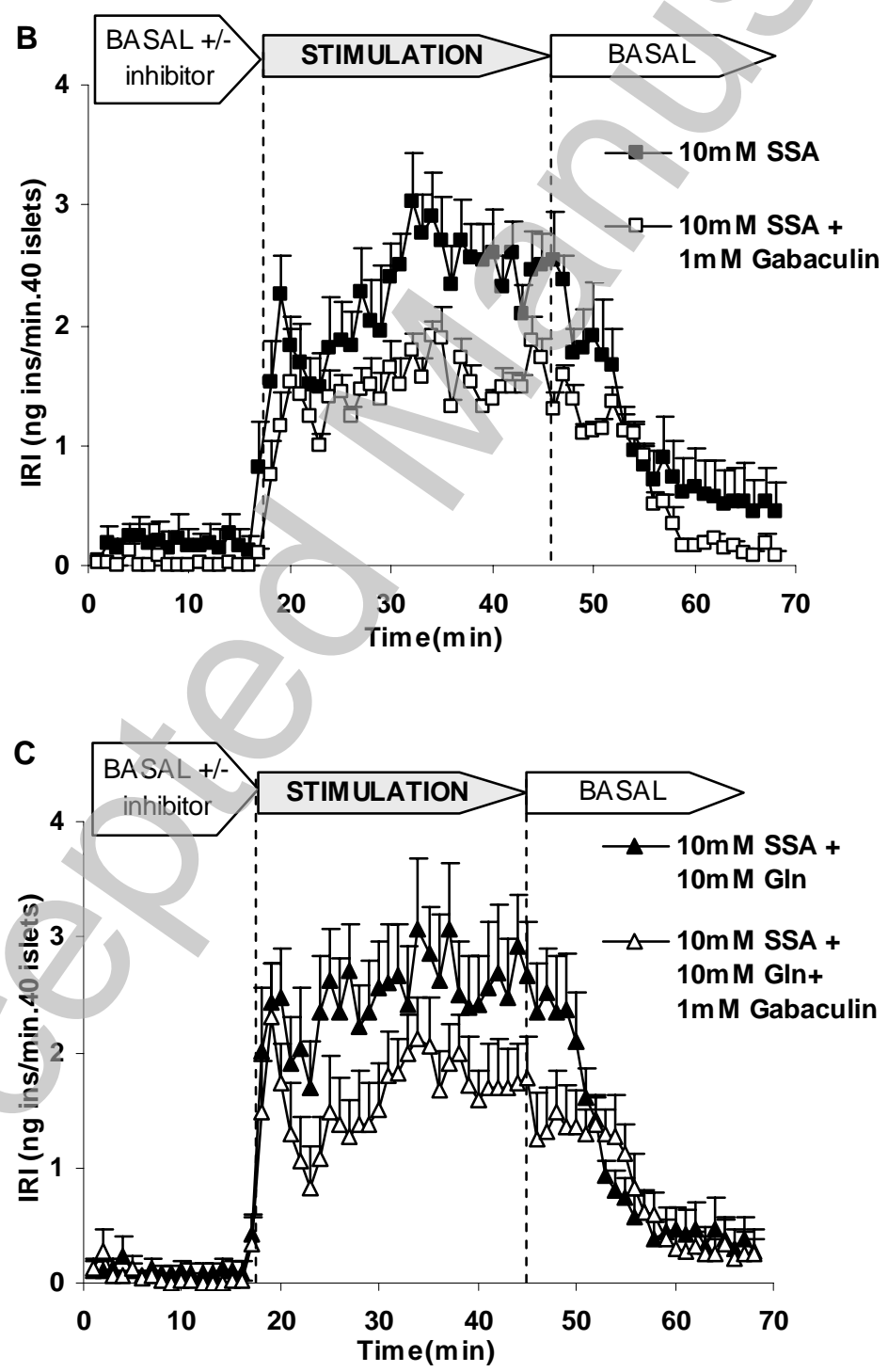

Figure 6 


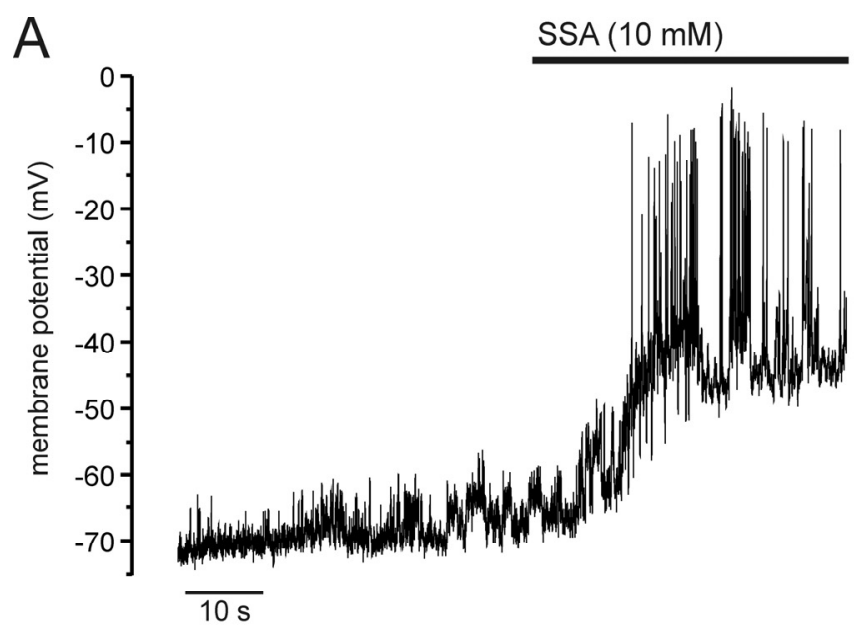

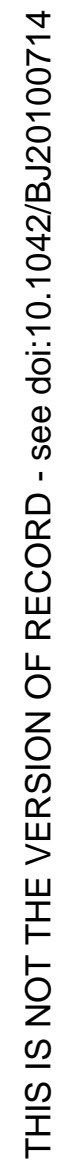
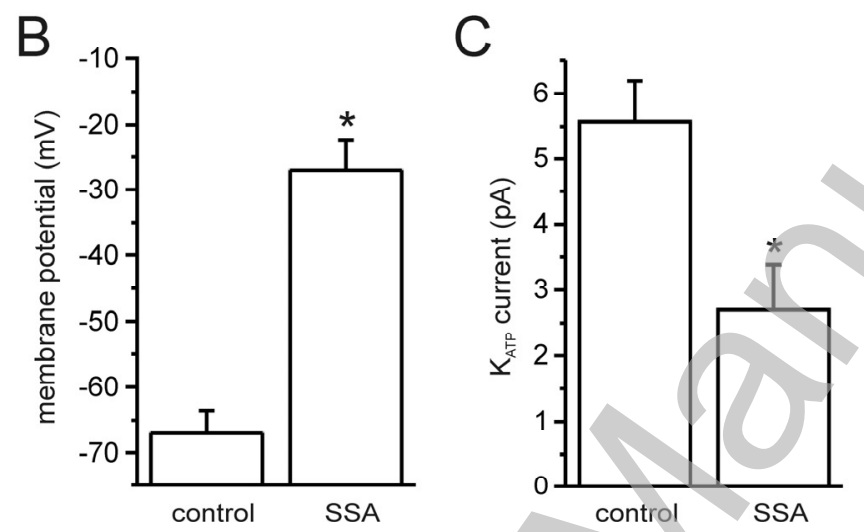

\section{Figure 7}

